Article

\title{
The Beneficiaries of Training Co-Financed by the ESF and Their Employability Market Orientation in Creating Labour Market Competitiveness
}

\author{
Przemysław Dubel * and Anna Pawłowska * \\ Faculty of Management, University of Warsaw, 02-678 Warsaw, Poland \\ * Correspondence: pdubel@wz.uw.edu.pl (P.D.); annap@wz.uw.edu.pl (A.P.)
}

Received: 29 September 2020; Accepted: 20 November 2020; Published: 21 November 2020

\begin{abstract}
The key objective of this article is to present the importance of human capital in the training process co-financed by the European Social Fund (ESF) in shaping sustainable economic development attitudes from the perspective of the labour market competitiveness. The presented research process focuses on the role of the psychological and competitive potential of individuals as workpreneurs on the modern labour market, showing an adaptive set of behaviours referred to as Employability Market Orientation. It has been assumed that one of its dimensions, which is Career Exploration, is of importance for the use of training as ESF interventions and is a manifestation of the scope of realization of the assumed goals under the European Union (EU) cohesion policy. CAWI type of research was carried out on a group of 840 Poles at the ages 18-60. The analysis of Pearson's $\mathrm{r}$ correlations led to the establishment of the existence of a relationship between participation in ESF training and Career Exploration (CE). Persons with high CE indicated more frequently than the remaining respondents that ESF training had increased their competitiveness on the labour market, whilst there were fewer of those who noted they had brought them no benefits. On the other hand, no relationship was identified between CE and non-participation in EFS training on account of poor adjustment of the offer to the needs of the labour market. A conclusion may thus be drawn from the obtained results that regions in which individuals show diverse levels of $\mathrm{CE}$ features will avail of the training co-financed from the ESF to a varying degree, regardless of their form or efficiency of their procedures. The role of human capital potential was thus confirmed in realizing the basic goals of the EU cohesion policy.
\end{abstract}

Keywords: labour market; human capital; Employability Market Orientation; workpreneur; ESF; training; regional policy; labour market competitiveness

\section{Introduction}

Actions implemented under cohesion policy (regional policy) of the EU are considered mainly from the perspective of macro and micro-economy. Regional disparities are referred to as the level of their economic development, which translates into more or less aggregated indicators. It seems that, from this perspective, the importance of an individual is underestimated and yet it is individuals that, through their activity on a mass scale, cause the expected processes, designated by the goals of regional policy. Apart from the reports of the EU, consulting companies [1] and regional public institutions [2], there are few scientific elaborations that would be devoted to the role of human capital potential that the region has at its disposal within its process of offsetting development disproportions, thanks to the EU intervention instruments. The issue of boosting entrepreneurial attitudes and actions, as well as establishing own businesses [3-5], is predominant here, also in the international context [6]. 
The region in which inhabitants reveal a higher potential than elsewhere upon the same level of financial expenditure will better use it, reaching the expected economic results faster, especially in the case of creating a competitive labour market.

Identifying the aspects of human capital potential that are essential in this context would be beneficial for the efficiency of impacts of the regional policy. Therefore, the above has been the subject of scientific interest in this article. In particular, the authors concentrated on individual recipients of the intervention, that is, training offered under the ESF in Poland.

\section{European Social Fund and Its Interventions for Building a Competitive Labour Market in Poland}

The EU has, for many years, strived to eliminate the differences between various regions in terms of their development in multiple areas and aspects. The key provision that regulates the above is Article 174 of the Treaty on the Functioning of the European Union (TFEU), according to which in order to strengthen its economic, social and territorial coherence, the Union seeks to reduce the differences in levels of regional development.

Realization of the above provision is intended to guarantee financial interventionism targeted at achieving economic and social cohesion that ensures sustainable economic growth [7]. This interventionism is mainly reflected in the regional policy that plays a crucial role by ensuring that member states obtain assistance in realizing the EU objectives [8]. Actions of the regional policy are implemented by means of financial resources that stem from structural funds to include the European Regional Development Fund (ERDF), Cohesion Fund (CF) and European Social Fund (ESF).

In the case of the labour market, which constitutes the centre of interest of this article, we are dealing with the European Social Fund (ESF), launched in 1957 pursuant to the Treaty establishing the EEC. This fund co-finances actions of member states in the area of employment policy and sustainable development of the human capital, perceived from the perspective of uplifting qualifications and decreasing the level of social exclusion.

The European Social Fund is, above all, a dynamic tool of the employment policy and combats unemployment within the territory of the Community, is targeted at realizing tasks under the European Employment Strategy (in November 1997, during the Luxembourg Summit, the Amsterdam Treaty was adopted, forming the basis of the principles of the European Employment Strategy - this strategy defines the scale of tasks and actions of members states, designated to limit unemployment, reduce poverty and social marginalization) and ensuring sustainable growth of human resources, perceived from the perspective of qualifications and decreasing the level of social exclusion. Interventions are realized under the ESF cover, among others, such as growth and promotion of active labour market policy; combating the phenomenon of long-term unemployment; supporting actions in the scope of professional training; increasing the potential of qualified and flexibly adaptable personnel. Out of the total ESF budget, amounting to EUR 86 billion, more than EUR 75 billion will be designated for the support of sustainable employment of high quality, social inclusion and investments in education and training. The majority of funds will be allocated for employment and education, while $25 \%$ will be for social inclusion [9]. Division of co-financing among individual member states has been shown in Figure 1.

The analysis of obtained co-financing levels (Figure 1) has confirmed that Poland is the largest recipient of this form of financial support. The Polish system of interventions operates on the basis of the national operational programmes as instruments that impact the sustainable development of the labour market. Since Poland's accession to the European Union (2004), the ESF has supported the realization of its national programmes which, in line with the National Development Plan (NDP) for 2004-2006 (the NDP contains an analysis of the social-economic situation, whereby priority needs, the strategy for achieving goals and planned actions have been specified), the National Cohesion Strategy 2007-2013 (document defining the priorities and areas of use as well as the implementation system for the EU funds; determines actions in support of economic growth and employment increase), and the National Development Strategy 2020 (the main objective of the strategy is to enhance and use 
economic, social and institutional potential to ensure swift and balanced development of a member state and improve the quality of life of its inhabitants). The National Development Strategy contributes not only to increasing the competitiveness of the Polish economy but also creates the foundations of permanent, sustainable development. These programmes encompass, among others: Sectoral Operational Programme Human Resources Development, Operational Programme Human Capital and Operational Programme Knowledge, Education, Development.

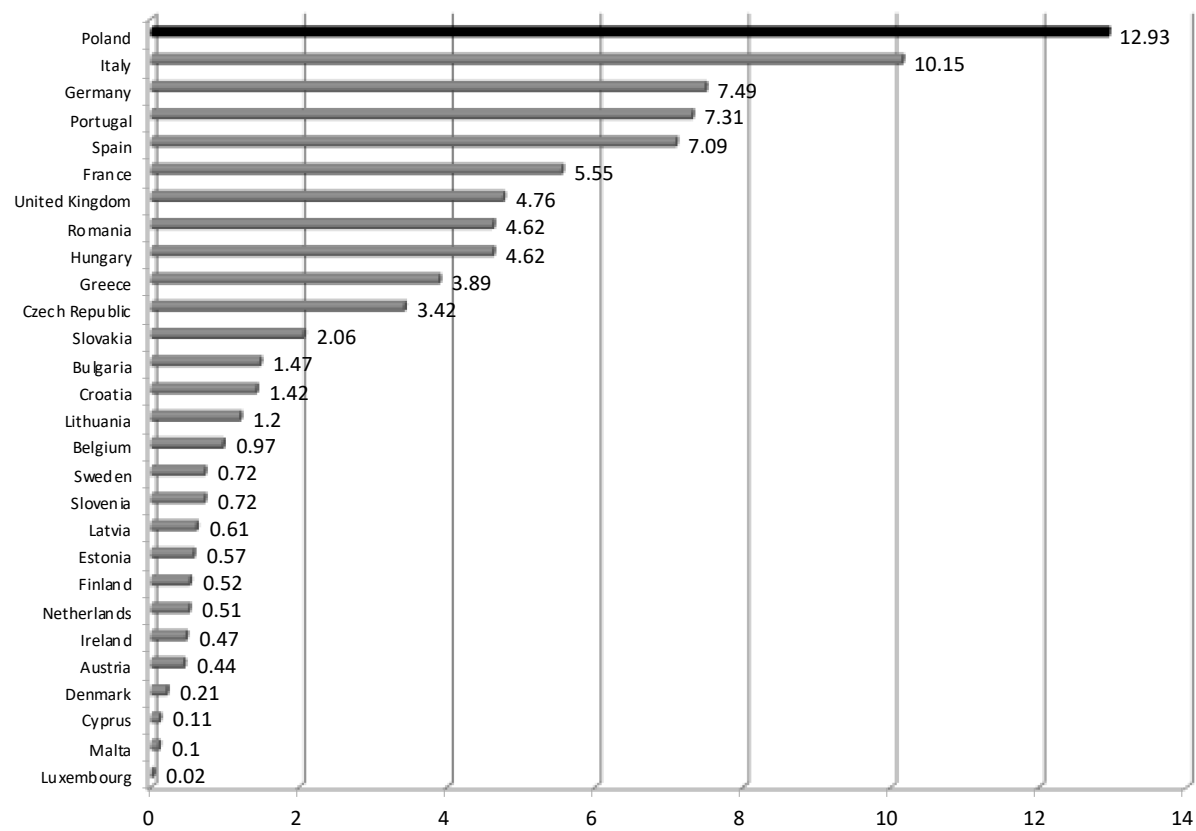

Figure 1. Division of co-financing under the ESF in EUR billions in the years 2014-2020. Source: https://ec.europa.eu/esf/main.jsp?catId=443\&langId=en.

In particular, within the current programming period (2014-2020) the national operating programme, which facilitates increasing the competitiveness of education, labour market and labour market institutions is the Operating Programme Knowledge, Education, Development (OP KED), constituting a continuation of the Operating Programme Human Capital. Shortening the period of unemployment, increasing professional qualifications, and improving employability are just some of the key objectives of the Polish socio-economic policy. The core areas of financial support under OP KED for the years 2014-2020 also include, aside from the strictly employment-related scope, geographical and professional mobility of employees, ability to carry out life-long learning, changes in the industry and in production systems necessary for sustainable development and support for the passage of young people from the educational stage to the stage of employment [10]. Under the training projects co-financed from national programmes, priority is given to young people up to the age of 29 (who remain unemployed) and to those aged 55+. Table 1 presents selected types of training and their potential beneficiaries.

The entirety of allocation under the ESF for OP KED amounts to approx. EUR 4.9 billion. The allocated funds are used on two levels—that is: regional and national — that have been divided within the percentage structure to reach $66 \%$ and $34 \%$, respectively. Within OP KED, EUR 2.4 billion was allocated for the promotion of permanent and high-quality employment and support of personnel mobility, which constitutes as much as $44 \%$ of the entire Programme allocation [9].

Thanks to the accepted assumptions, it is possible to realize actions supporting the search for better and more permanent workplaces while ensuring sustainable development both on the regional and international level. Realized projects are of individual character and their recipients are the most vulnerable social groups. 
Table 1. Types, acquired skills and potential beneficiaries of training co-financed from the ESF.

\begin{tabular}{|c|c|c|c|}
\hline No. & Types of Training & Skills & Potential Beneficiary \\
\hline 1 & $\begin{array}{l}\text { Vocational training increasing } \\
\text { employment opportunities, } \\
\text { aimed at enhancing the } \\
\text { competences or qualifications } \\
\text { necessary to perform job tasks }\end{array}$ & $\begin{array}{ll}- & \text { teamwork } \\
- & \text { motivation } \\
- & \text { willingness to self-develop } \\
- & \text { knowledge of the industry } \\
- & \text { knowledge of tools } \\
- & \text { teamwork }\end{array}$ & $\begin{array}{l}\text { Unemployed and young } \\
\text { people, lower and } \\
\text { middle-ranking employees }\end{array}$ \\
\hline 2 & $\begin{array}{l}\text { Increasing the adaptability of } \\
\text { the SME sector (micro, small } \\
\text { and medium-sized enterprises) } \\
\text { in the field of enterprise } \\
\text { management, including human } \\
\text { resource management, } \\
\text { innovative processes, } \\
\text { succession in family businesses, } \\
\text { development of compensatory } \\
\text { technologies }\end{array}$ & $\begin{array}{ll}- & \text { motivation } \\
- & \text { willingness to self-develop } \\
- & \text { conflict solving } \\
- & \text { logical thinking } \\
- & \text { motivating employees } \\
- & \text { delegation of powers } \\
- & \text { operation of tools } \\
& \text { supporting management } \\
\text { processes-e.g., MS Office, } \\
\text { MS Project }\end{array}$ & $\begin{array}{l}\text { Entrepreneurs, employees, } \\
\text { owners and co-owners of } \\
\text { companies }\end{array}$ \\
\hline 3 & $\begin{array}{l}\text { Management of public entities, } \\
\text { economic development and } \\
\text { deinstitutionalization }\end{array}$ & $\begin{array}{ll}- & \text { teamwork } \\
- & \text { flexibility } \\
- & \text { assertiveness } \\
- & \text { self-management } \\
- & \text { planning and organization } \\
- & \text { teamwork }\end{array}$ & Public sector employees \\
\hline 4 & $\begin{array}{l}\text { Certified training and } \\
\text { workshops, including the } \\
\text { development of soft skills }\end{array}$ & $\begin{array}{ll}- & \text { motivation } \\
- & \text { creativity } \\
- & \text { dynamism of action } \\
- & \text { independence } \\
- & \begin{array}{l}\text { use of tools for remote work } \\
\text { (virtual jobs) }\end{array}\end{array}$ & $\begin{array}{l}\text { Administrative staff, lecturers } \\
\text { and students }\end{array}$ \\
\hline 5 & $\begin{array}{l}\text { Improving the efficiency of the } \\
\text { health care system, with } \\
\text { particular emphasis on the } \\
\text { development of analytical skills } \\
\text { and internal audit }\end{array}$ & $\begin{array}{ll}- & \text { teamwork } \\
- & \text { creativity } \\
- & \text { self-management } \\
- & \text { planning and organization } \\
- & \text { ethics } \\
- & \text { human } \\
& \text { resource management }\end{array}$ & Health sector employees \\
\hline
\end{tabular}

Source: own elaboration.

The fact that Poland is the main recipient of interventions under the ESF makes this region a unique area of research, the outcomes of which have been described in this article. One of the instruments of impacting the labour market participants—i.e., training—has been scrutinised.

\section{The Role of an Individual in Using ESF Interventions and Stimulating the Regional Cohesion Processes on the Labour Market}

In this article, training financed from the ESF is treated as an instrument supporting the sustainable development of regions in the area of labour market competitiveness. Simultaneously, it is noted that this development is uneven. It is therefore interesting to check the cause of this diversification. The question arises, however, what to consider when analysing this phenomenon.

In the presented article, the proposed starting point is the fact that one of the main factors influencing the region's competitiveness is the behaviour of its inhabitants who should be treated as human capital. 
Inherently, the intervention in the form of ESF-financed training is aimed at reaching those beneficiaries who potentially slow down the region's development in terms of the labour market competitiveness.

This will thus trigger their behaviours that will initiate the expected processes, as shown in Figure 2.

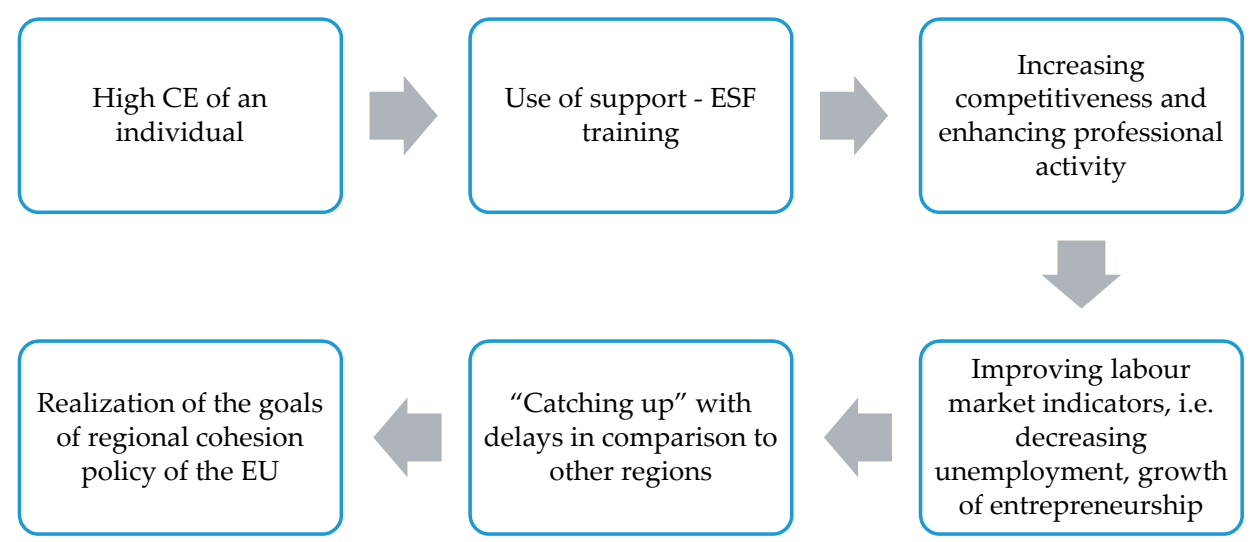

Figure 2. The role of human capital potential in realizing the EU objectives. Source: own elaboration.

More broadly, the activity of individuals will result in economic changes, which will be reflected in the improvement of economic indicators of regional development.

The fundamental idea of ESF-financed training is therefore to exert such an impact that the established intervention system reaches the widest possible group of beneficiaries. Nonetheless, it is especially important that it reaches those who are passive and not self-reliant on the labour market.

Ergo, the aim of the research presented in the article is to check whether training co-financed from the ESF reach the group of beneficiaries whose psychological and competence potential does not allow them to be active on the labour market on their own, thus determining the potential cause of delays in the region's development and possibly inhibiting cohesion processes.

Correct identification of those individual properties that may be of importance in this particular context for the use of training under the ESF and the realization of basic goals of the regional policy with regard to labour market competitiveness is crucial for such stated research objective [11]. Undoubtedly, these features ought to be sought initially in the scope of vocational functioning of an individual in response to the phenomena occurring on the present-day labour market.

\section{An Individual as a Workpreneur with Employability Market Orientation on the Modern Labour Market}

One of the phenomena that any participant in the modern labour market is faced with is the fact that the mode of employment in one workplace for the whole life has disappeared. This means that a significant number of persons will change their work and profession multiple times [12]. Actions must thus be undertaken that will limit the duration of remaining without work to the minimum, guaranteeing fast reinstitution of a subsequent income source [13,14].

A. Pawłowska discovered in her research that Employability Market Orientation (EMO) is an adaptive attitude of an individual, decreasing the feeling of job insecurity in this situation, that covers five types of activities: Career Exploration (CE), Future Time Perspective (FTP), Vocational Self-Concept Crystallization (VSCC), Career Planning (CP) and Career Strategy Implementation (CSI) [15]. This is a certain pattern of behaviours that must be activated on a continuous basis by individuals, also while being employed, considering the conditions present on the modern variable labour market. Thanks to this, they become workpreneurs [16] offering the skills of "sale" on the labour market.

Due to the fact that EMO is a rather complex structure, the research presented in this article has been focused on the dimension of Career Exploration that seems to be of particular importance for the 
use of training under the ESF, organized in line with the European and Polish Quality Framework for Internships and Apprenticeships.

They serve the purpose of activating individuals who remain without employment through obtaining or supplementing professional experience and competencies as well as qualifications necessary on the labour market [17].

Hence, it is assumed that Career Exploration by an individual is the dimension that may constitute an important component of the human capital potential and it would seem worthwhile to include it in research when realizing the goals assumed in this article.

\section{Career Exploration as an Element of Employability Market Orientation versus the Use of ESF Training}

In the literature, concerning professional development of individuals, one may encounter two concepts with similar meanings that refer to the functioning of an individual on the labour market. Q. Wenga, J.C. McElroy [18] and J. Koen, U.Ch. Klehe, A.E.M. Van Vianen, J. Zikic and A. Nauta [19] apply the term "career exploration" while H. Flum and L. Blustein [20] "vocational exploration", although their conceptual scope is practically identical [21].

Both concepts concern internal exploration of features, values, interests and skills of an individual as well as exploration of external factors (environmental career exploration), possibilities, options, educational conditions, professional conditions and generally the relational context of professional environment.

In order to apply this term correctly with respect to the modern reality, it is crucial to specify the manner of its comprehension. All the more, when its definition has changed along with the shifting approach to professional development and career. H. Flum and L. Blustein [20] carried out a historical analysis of approaches to the concept of "exploration". One of the first people to apply it was F. Parsons [16], according to whom exploration of oneself and of the work world is critical for taking the right professional decisions.

At the initial stage of research on exploration (according to H. Flum and D.L. Blustein, we can refer to the 1950s and researchers such as D. Super, F. Harren, F. Tiedeman and S. O'Hara [20]), it was analysed depending on the stage of professional development or at the time of taking decisions related to one's career. At the time, professional exploration as an activity would appear at the time of changing the stage of one's career, pursuing a promotion at work or more or less forced decisions on changing one's workplace. In light of the prevailing long-term employment, exploration activity activated itself relatively seldom and rather incidentally.

Nowadays, the labour market reality and the short-term nature of employment trigger the necessity of changing the way of perceiving professional exploration. As human experience becomes increasingly complex and diverse as a result of social, economic and political changes, our perception of the psychological construct of exploration must be expanded so as to match the expanding borders assigned to this phenomenon [20].

Thus, a new generation of research on exploration has recently appeared. Researchers postulate the introduction of a definition the scope of which is substantially broader and covers more elements. Professional exploration, according to J. Zikic and A.M. Saks [22], consists of gathering significant and useful data from the point of view of individual professional development. It comprises the exploration of one's own skills (auto-exploration) and professional environment exploration. The former element is the gathering of data about oneself and one's possibilities of employment. Thanks to this, individuals are more conscious and sensitive about their value, interests and talents just as about the chances in their environment. The second element covers investigation by an individual of different options of career provided by a given employer through an active search of information on work offers, organizations, professions or industries which results in more conscious professional decisions.

It is particularly important to consider the fact that exploration ought to be regarded as a process that lasts throughout life, supporting one's copying with work changes, transitional situations in the 
course of professional functioning of an individual. It is thus treated as a continuous process that runs in a volatile system. It is tied to a flexible approach and constitutes a reply to more fluxional and unpredictable professional experiences.

One must clearly stress that professional exploration is not simple browsing through work offers. In line with this perspective, persons with a high level of exploration never focus solely on searching for just one type of profession, place of work, but rather expand their search activities by seeking different types of works and industries as well as observing activities of other workpreneurs [19]. Exploration, therefore, is supposed to be a reply to unplanned and accidental professional experiences. Hence, it becomes significant in situations of job insecurity. Presently, researchers are analysing the effectiveness of exploration and its nature, but this is no longer linked to the stages of one's career.

According to H. Flum and L. Blustein [20], professional exploration is a key initiating step that prepares job searchers for behaviours that are more adaptive as such and lead to employment. This is confirmed by Q. Wenga and J.C. McElroy [18], who claim that the course of this process is of importance for taking effective professional decisions. The process of exploration, due to its orientation towards gaining self-knowledge and information in the context of the environment, is possible thanks to the motivation of individuals, their attitude and engagement. At the same time, two skill sets are necessary that are targeted at developing and gaining experiences in exploration activities.

In order to boost and develop competitive competencies that are crucial for the EU labour market, individuals must undertake actions typical for the Career Exploration.

Therefore, for the presentation purposes of research in this article, an assumption was accepted that persons showing CE are active labour market participants and avail of ESF training, since thanks to them they are able to update their portfolio of competencies as per the labour market needs in place, thus improving their competitiveness $[23,24]$. This, on the other hand, will trigger the subsequent professional activity that supports cohesion processes on the labour market in line with the designated objectives of the regional policy with respect to the labour market.

Due to the above-specified reasons, $\mathrm{CE}$ as a feature has been considered by individuals as fitting the research the goal of which is to verify the importance of human capital potential in ESF interventions targeted at improving inter-regional cohesion on the labour market.

In the subsequent part of the article, certain hypotheses were formed which were then tested in the framework of realizing the objectives of this paper.

\section{Hypothesis Development and Research Procedure}

As argued in the previous sections, CE of individuals may consist of human capital potential that supports the use of training co-financed from the ESF, accelerating the expected economic processes that are significant for the regional development.

If a given region has a shortage of persons with CE, the ESF intervention may not bring the anticipated economic results. Potentially, CE may thus decrease the efficiency of using ESF resources and goals to be achieved by the cohesion policy.

The analysis of types of ESF interventions shows that a factually efficient system of improving competitiveness on the labour market through training ought to support all active individuals (with high CE) as well as those passive ones (with low CE). Participation in training co-financed from the ESF by individuals thus ought to be independent of the level of $\mathrm{CE}$ they possess. The applied procedures as well as the system of communication and incentives ought to function in such a way as to enable the instrument of support under the ESF to reach and encourage all to participate in the training.

If there is a link between $\mathrm{CE}$ and the use by individuals of this form of financial support, then such training is attended by active persons with high $\mathrm{CE}$, which contradicts the assumptions of ESF and thus limits inter-regional cohesion on the labour market. Therefore, the below hypothesis was tested. 
Hypothesis 1 (H1). There is a positive correlation between participating in training co-financed from the ESF and $C E$.

Apart from this, the analysis ought to include the issue of assessing the benefits from a given training by its participants. Within the system of support that realizes the adopted goals, all participants, regardless of their level of CE (active and passive), ought to indicate that it has increased their competitiveness on the labour market.

If there is a link between high CE and an indication that the training has increased one's competitiveness; this would mean that only active individuals obtain the right support while the passive ones are deprived of it. Thus, the below hypothesis was formulated.

Hypothesis 2 (H2). There is a positive correlation between high CE and the respondent's indication that training has increased his/her competitiveness on the labour market.

It is also worth taking a closer look at a reverse situation; that is, the nature of the relationship between $\mathrm{CE}$ and an indication that training has brought no benefits to the participant. Persons with a high CE, who actively and consciously participate in the labour market, ought to avoid such situations and, for this reason, they should indicate this answer less frequently when assessing training co-financed from the ESF.

Nonetheless, in a well-functioning training intervention, none of the groups, regardless of the level of $\mathrm{CE}$, should indicate such an answer. The appearance of a negative dependency between $\mathrm{CE}$ and the answer that a given training was useless may be treated as a signal regarding lack of realization of the assumptions of an intervention under the ESF regarding reaching everyone-both active and passive participants.

Hypothesis 3 (H3). There is a negative correlation between high CE and an indication of a reply that a given training did not bring any benefits.

The most unbeneficial for the efficiency of training co-financed under the ESF would be to identify the relationship between a decision not to participate in such training due to ill adjustment of a given offer to the needs of the labour market and CE. This would mean that persons who are active, observe the labour market - that is, show characteristics significant from the point of view of development, do not receive support in the direction specified by the regional policy. Therefore, the below hypothesis is worth verifying.

Hypothesis 4 (H4). There is a positive correlation between CE and non-participation in training co-financed under the ESF on account of non-adjustment of a given offer to the needs of the labour market.

As stated in the previous chapter concerning the ESF, within the research process presented in this article, the above-specified hypotheses (Figure 3) have been tested using Poland as the example due to the fact that it is the largest receiver of ESF financial interventions. The choice of only one country in this case is justified, as it allows for eliminating the impact of the national culture on decisions regarding participation in training [25]. 


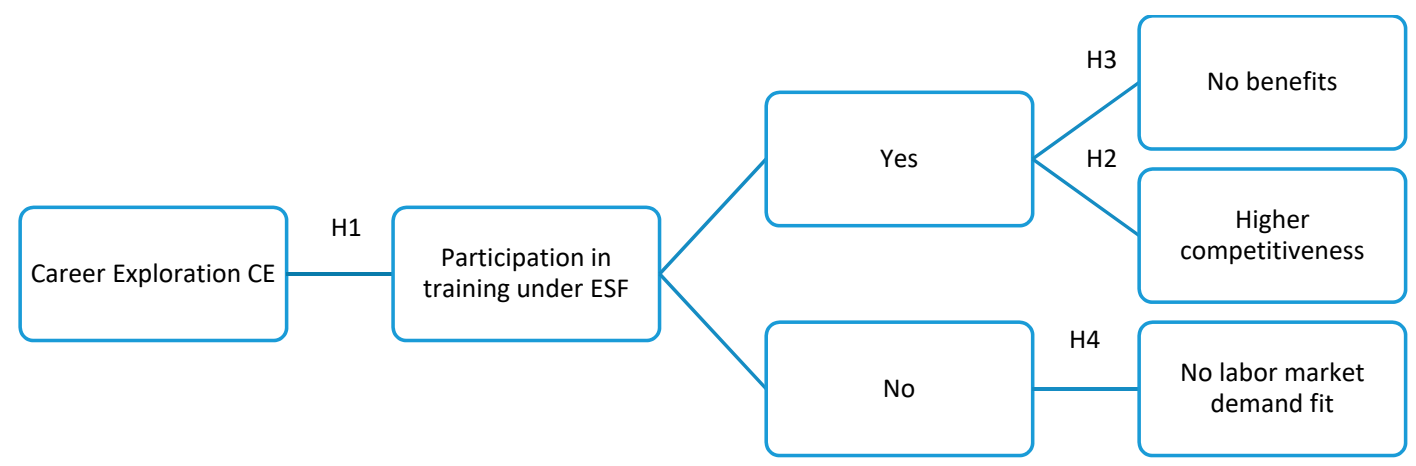

Figure 3. The scheme of presented hypotheses for verification in the research process. Source: own elaboration.

Bearing in mind the specificity of Poland and the national goals of operating programmes co-financed under the ESF, apart from age and sex, also other variables have been considered within the research process.

Since raising competencies appears to be important, education has been also taken into consideration. What is more, the type of employment (full-time versus own economic activity) has been tested, as well as planning a change in employment/type of economic activity carried out in the context of mobility on the labour market. In light of the fact that the ESF funds are targeted at supporting regions with a lower level of development, one might also assess the place of residence (countryside, small, medium or large town and city).

The below Table 2 summarizes all the tested variables with the markings applied in the part that presents research outcomes.

Table 2. Summary of diagnosed variables along with the markings.

\begin{tabular}{cc}
\hline Variable & Marking \\
\hline ESF training participation & TP \\
Career Exploration & CE \\
EFS training participation evaluation-higher competitiveness & HC \\
EFS training participation evaluation—-no benefits & NB \\
No EFS training participation-no labour market demand fit & NTPL \\
Job/business change planning & JC \\
Place of residence-village, small, medium, big town and city & PR \\
Age & Age \\
Sex & Sex \\
Education & ED \\
Type of employment-traditional employment/running own business & TE \\
\hline
\end{tabular}

Source: own elaboration.

\section{Method}

\subsection{Diagnostic Tools and Manner of Result Analysis}

The key variable for the research presented in this article, Career Exploration (CE), was diagnosed by means of the scale elaborated by A. Pawłowska [15].

Upon shaping the scale, the author was inspired by the diagnostic tools elaborated by Van der Heijde, C.M. and Van der Heijden, B.I.J.M. [26] as well as Stumpf, S.A., Colarelli, S.M. and Hartman, K. [27].

Questions were however selected for the final version of the scale in a manner that was justified from the point of view of the Polish labour market reality and thus, some of the questions were abandoned while other, new ones, were inserted. Especially in the course of translation into Polish, a 
modification was introduced to the initial version of the questions so that they were more adequate culturally, whilst no scale was applied in the original version.

Eventually, the scale of Career Exploration (CE) was applied consisting of eight items, targeted at pursuing replies to the question whether an individual monitors vocational environment; that is, the needs of potential clients-employers in terms of the skills he or she possesses. In the assumed diagnostic approach, types of activities of an individual in the following scopes were measured:

- Controlling the existing employment possibilities on the labour market—assessment of the volume and type of job offers;

- Developing or obtaining new competencies due to the anticipated increase in demand;

- Estimating own competitive position in comparison to other potential employees with a similar portfolio of competencies.

In the earlier research targeted at elaborating the scale of Career Exploration (CE) [15], Cronbach's alpha for the scale amounted to 0.85 . The set of questions comprising the scale is presented in Table 3 .

Table 3. Items for the scale of Career Exploration (CE).

\begin{tabular}{cl}
\hline No. & Evaluate on the Scale How Frequently the Below Occur to You: \\
\hline 1. & I browse through the labour market and observe the expectations of employers. \\
2. & I analyse job offers that are a chance for my professional development. \\
3. & I observe which forms of additional education are undertaken by the persons from my professional environment. \\
4. & I check the number of potential job offers suitable for me on the market. \\
5. & I am aware of the professional careers pursued by others in my profession. \\
6. & I search for information concerning a specific job or company as a potential workplace for me. \\
7. & I regularly have conversations with persons who are well-informed about matters related to my profession. \\
8. & I gather information about ways of adjusting to various professional development paths. \\
\hline & The scale of answers: (1) never; (2) seldom; (3) frequently; (4) very frequently. Source: own elaboration.
\end{tabular}

The subsequently diagnosed variables refer to training co-financed under the ESF. The respondents answered the following yes/no questions: Have you ever participated in training co-financed from the EU funds? If they responded positively, in the subsequent question concerning the benefits of training, they had to select from amongst five possible answers of which two below were subjected to the analysis upon verifying the hypotheses: Increasing my competitiveness on the labour market, or, I gained nothing.

If the respondents replied that they had not participated in any such training, they had to select from amongst four answers out of which the answer, Not adjusted to the needs of labour market, was analysed upon verifying the hypotheses. A question was also asked about whether the respondent is planning within the upcoming year to change work or change the line of business they carried out. The remaining information, such as age, sex, education, place of residence and type of employment was obtained from the personal information provided in the questionnaire.

The analysis of results and verification of hypotheses were conducted on the basis of Pearson's $\mathrm{r}$ correlation coefficient (phi coefficient).

\subsection{Characteristics of the Tested Group}

An external, specialist company was entrusted with the conduct of the test. The questionnaire was carried out on a representative sample of 1053 Poles via Computer Assisted Web Interview (CAWI) method with the use of an online survey (Appendix A). It is a technique for collecting information in opinion research, in which the respondent is asked to complete an electronic questionnaire. The replies to questions presented in this article, provided by respondents within the age group of 18-60, were analysed, which led to the final group of 847 respondents, whereby the following number of persons was noted in the respective age ranges: $13.6 \%$ (115) of those $18-24$ years old, $24.4 \%$ (207) of those 25-34 years old, $21.5 \%$ (182) of those $35-44$ years old, $22.4 \%$ (190) of those $45-54$ years old, $18.1 \%$ (153) of those 55-60 years old. 
Among the tested respondents, there are 47\% (397) of men, 53\% (450) of women, 43\% (367) of persons with bachelor (BA), master (MA), doctoral and other education. Within the tested group, $39 \%$ (330) of respondents live in the countryside, 14\% (116) in a small town, 19\% (162) in a medium town, $16 \%$ (138) in a large town and $12 \%$ (101) in a large city. Furthermore, $75.6 \%$ are employed (have a job), 9.6\% (81) have their own business activity and 18.5\% (157) are planning to change work or type of business activity carried out.

7.2.1. Participation of Respondents in Training Co-Financed from the ESF and Their Assessment of Enhancing Competitiveness on the Labour Market

The figure below (Figure 4) provides a summary of data describing the tested group by their participation or non-participation in training as well as their assessment of enhancing competitiveness on the labour market with a division into age, sex, education and place of residence.

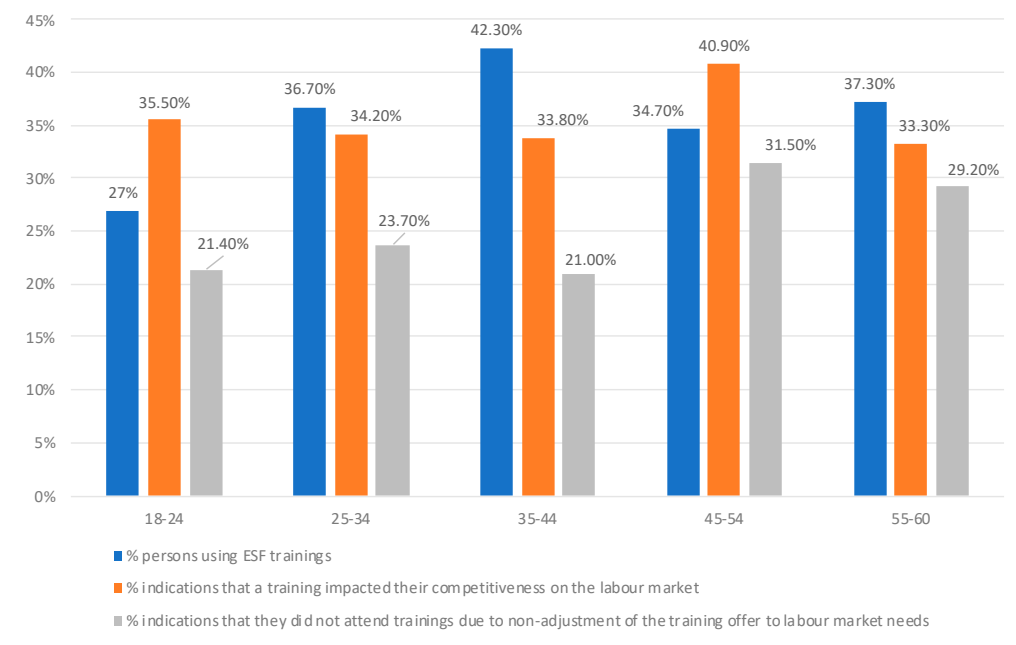

(a)

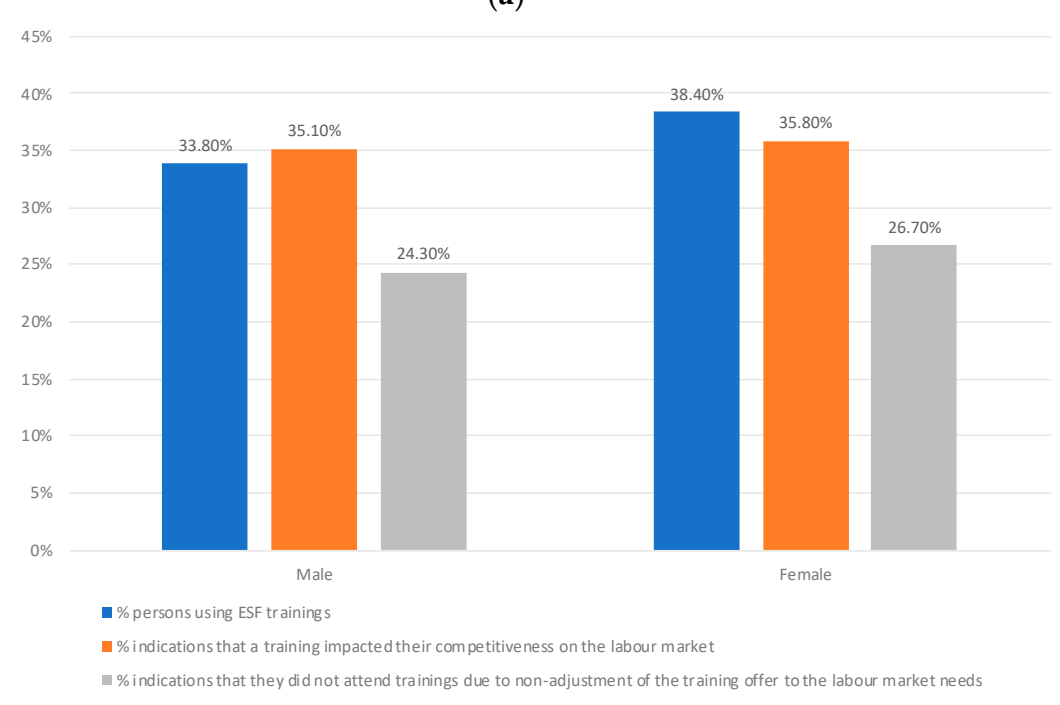

(b)

Figure 4. (a) Attendance by age and participation or non-participation in training under the ESF and assessment in terms of increasing competitiveness on the labour market, (b) Percentage summary by sex and participation or non-participation in training under the ESF and assessment in terms of enhancing competitiveness on the labour market. Source: own elaboration. 
(a) As may be noticed, the proportion of persons using training (above $42 \%$ ) concerns beneficiaries at the age of 35-45, of which $33 \%$ considered training to have increased their competitiveness on the labour market. Within this tested group, only $21 \%$ of respondents did not attend training co-financed under the ESF due to their non-adjustment to the needs of the labour market. Non-adjustment of the training offer stems most frequently from non-implementation of the results of the conducted research processes related to adjusting the training offer to the needs of future employers and the developing market competitiveness.

(b) The predominant share of women (38.4\%) stems from the specificity of the ESF and the overall trend as regards the number of interested persons (divided by sex) who participate in this type of training. It is noticeable that the percentages of persons who did not participate in this form of co-financing amount to M: $24.3 \%$ and $\mathrm{W}: 26.7 \%$, respectively. We may also conclude that women more willingly avail of the forms of training offered by the ESF.

Breakdowns in the obtained results in terms of education and size of residential area have been presented in Figure 5.

(a) The group of persons most often attending training co-financed under the ESF turned out to include persons with primary education (50\%) and BA education (57.1\%). Within these groups, $45.5 \%$ and $27.3 \%$ of the respondents, respectively, noted that they had not used this form of support due to non-adjustment of the training offer to the needs of the labour market. As may be noted, especially in the group of persons with primary education, this level is quite significant. It is substantial information for the process of planning future training for this type of recipients.

(b) Within the breakdown in terms of the area of residence, persons living in the countryside availed of the training offer co-financed under the ESF most willingly $(38.8 \%)$, as well as persons living in cities with a population above 20,000 inhabitants (40.5\%). Respectively, for these groups the shares of persons not availing of the offered training also amounted to $19.8 \%$ and $20.0 \%$. The analysis of the obtained results shows that one of the factors impacting the efficiency of ESF spending is the level of adjustment of the training offer to the needs of the labour market. Almost $1 / 3$ of the tested persons indicated that the present programming process of offered training under the ESF in Poland does not coincide with market expectations.

\subsubsection{Level of Career Exploration in the Tested Group}

The respondents showed $\mathrm{CE}$ at an average level of $\mathrm{M}=2.441$, standard deviation $\mathrm{SD}=0.63$. Within the tested group, $46.9 \%$ (450) of persons obtained the result on the CE scale above the median, thus, high. This has been presented in Figure 6 .

Yet another figure (Figure 7) presents a summary of data describing the tested group by a low or high result of CE and the participation or non-participation in training co-financed under the ESF as well as the assessment in terms of increasing competitiveness on the labour market.

Within the tested group, more persons with a high than low level of $\mathrm{CE}$ attended training co-financed under the ESF ( $43.1 \%$ ) and indicated that the training impacted their competitiveness on the labour market $(40.2 \%)$. On the other hand, more persons with a low level of CE (26.1\%) indicated that they had not attended the training due to non-adjustment of the training offer to the needs of the labour market. 


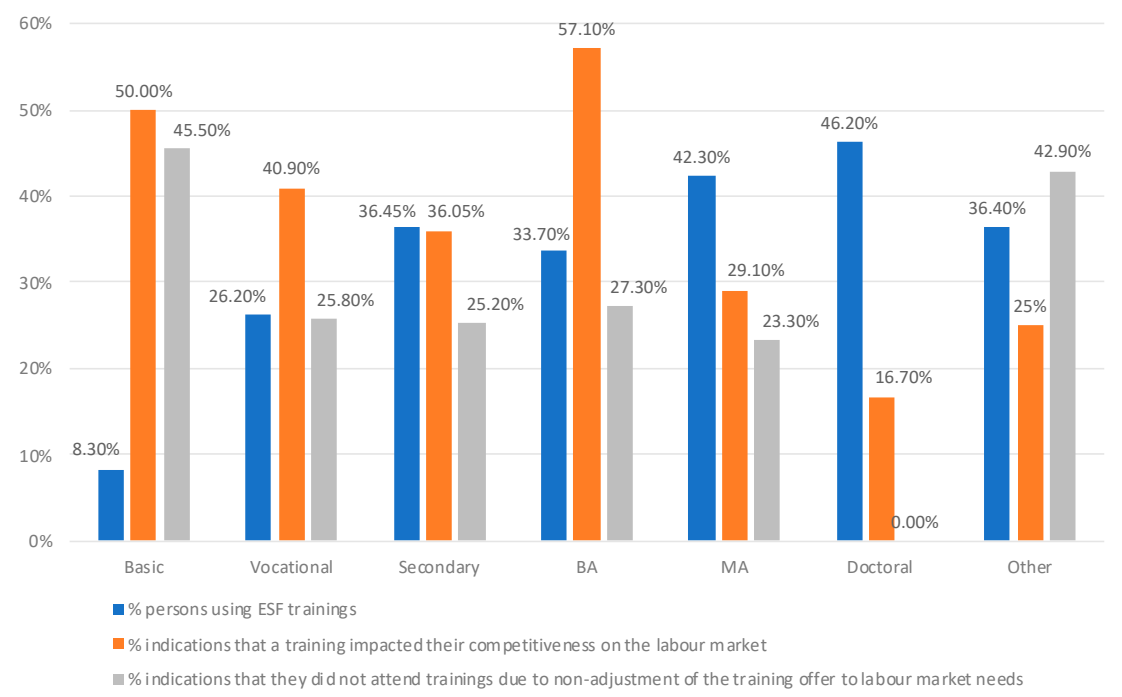

(a)

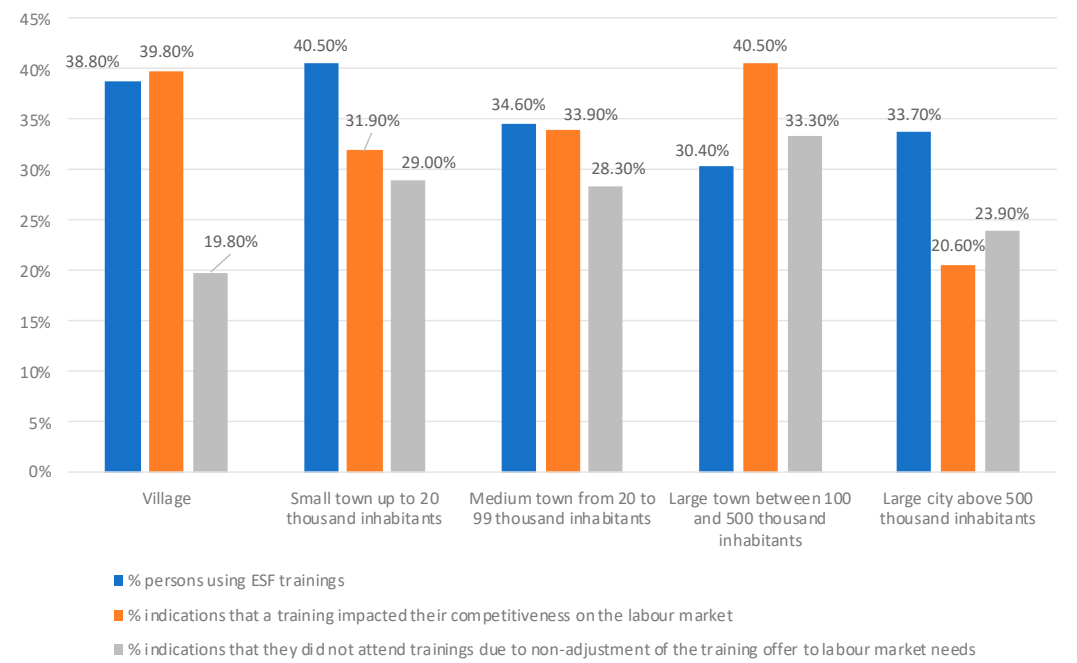

(b)

Figure 5. (a) Attendance by education, participation or non-participation in training under the ESF and assessment in terms of increasing competitiveness on the labour market, (b) Percentage summary by place of residence, participation or non-participation in training under the ESF and assessment in terms of enhancing competitiveness on the labour market. Source: own elaboration. 


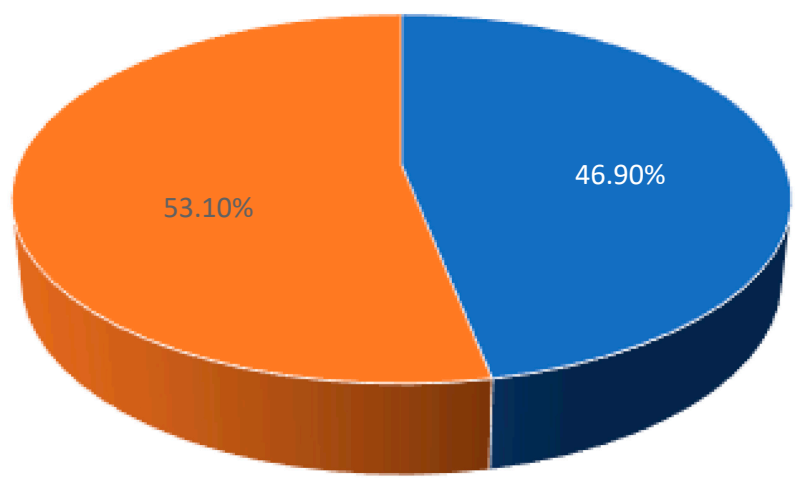

- Low Career Exploration - High Career Exploration

Figure 6. Attendance of persons with high and low Career Exploration (CE) in the tested group. Source: own elaboration.

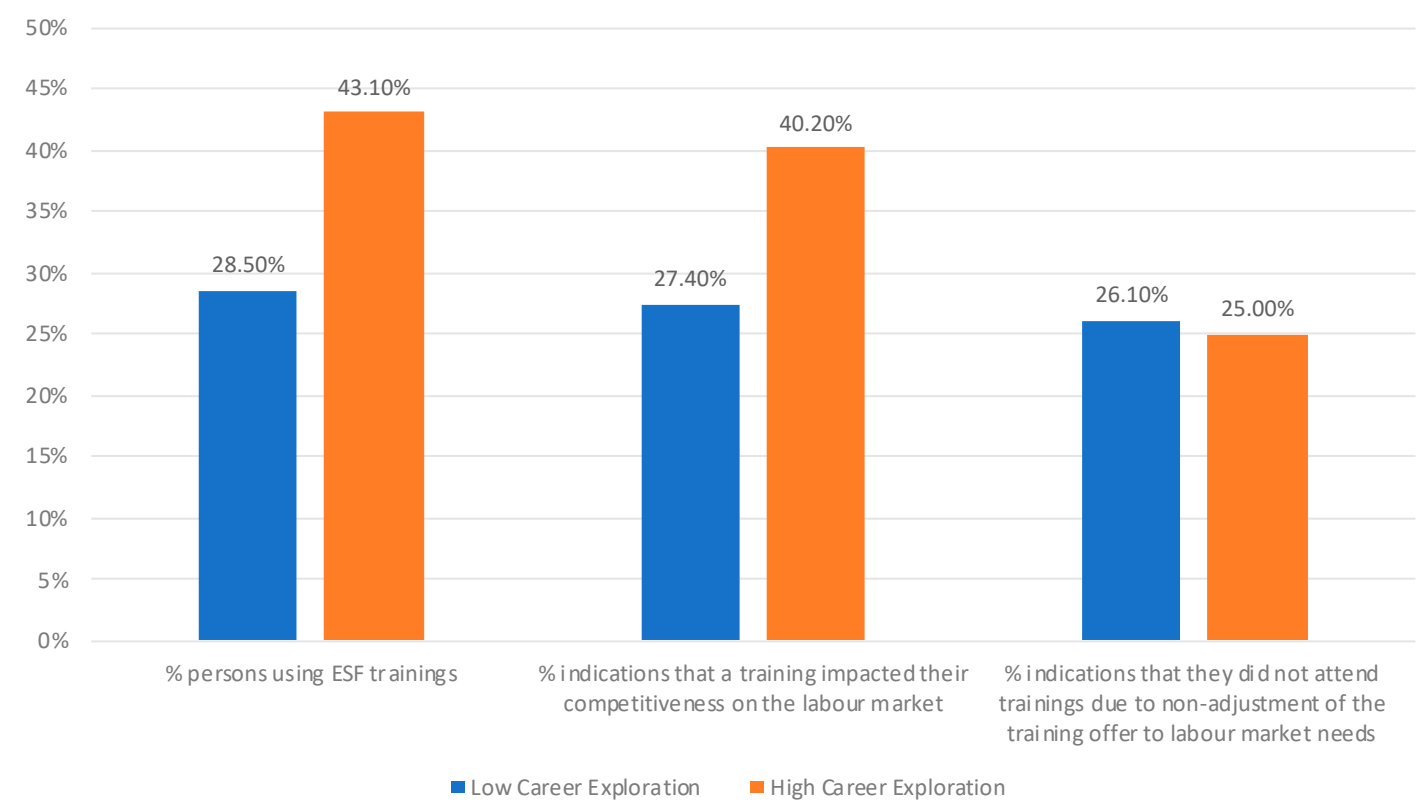

Figure 7. Attendance by a high and low level of Career Exploration (CE) and participation or non-participation in training under the ESF as well as the assessment in term of increasing competitiveness on the labour market. Source: own elaboration.

\section{Results and Verification of Hypotheses}

The below Table 4 shows Pearson's r correlation coefficients targeted at verification of the basic hypotheses.

As a result of the conducted correlation analysis on the basis of Pearson's $r$ coefficient, three amongst four stated hypotheses were confirmed. A summary of the hypotheses and the effects of their verification can be found in the table below (Table 5). 
Table 4. Summary of Pearson's r correlation coefficients.

\begin{tabular}{|c|c|c|c|c|c|c|c|c|c|c|c|c|}
\hline & Variable & Sex & Age & PR & ED & $\mathrm{JC}$ & TP & HC & NB & NTPL & TE/RB & $\mathrm{CE}$ \\
\hline Age & & -0.01 & & & & & & & & & & \\
\hline PR & $\begin{array}{l}\text { Place of } \\
\text { residence-village, small, } \\
\text { medium, big town and } \\
\text { city }\end{array}$ & 0.04 & $0.09 *$ & & & & & & & & & \\
\hline ED & Education & 0.03 & $0.09 *$ & $0.13^{*}$ & & & & & & & & \\
\hline JC & $\begin{array}{l}\text { Job/business change } \\
\text { planning }\end{array}$ & -0.02 & $-0.22 *$ & 0.03 & $0.09 *$ & & & & & & & \\
\hline TP & $\begin{array}{l}\text { ESF training } \\
\text { participation }\end{array}$ & 0.05 & 0.04 & -0.06 & $0.13 *$ & 0.05 & & & & & & \\
\hline $\mathrm{HC}$ & $\begin{array}{l}\text { ESF training } \\
\text { participation } \\
\text { evaluation-higher } \\
\text { competitiveness }\end{array}$ & 0.01 & 0.01 & -0.08 & -0.07 & 0.02 & - & & & & & \\
\hline NB & $\begin{array}{l}\text { ESF training } \\
\text { participation } \\
\text { evaluation-no benefits } \\
\text { no EFS training }\end{array}$ & 0.01 & 0 & 0.02 & 0.05 & $-0.04 *$ & - & -0.65 & & & & \\
\hline NTPL & participation-no labour & 0.03 & 0.08 & 0.08 & -0.04 & $-0.12 *$ & - & - & - & & & \\
\hline $\mathrm{TE} / \mathrm{RB}$ & $\begin{array}{l}\text { Type of } \\
\text { employment-traditional } \\
\text { employment/running } \\
\text { own business }\end{array}$ & -0.02 & $0.09 *$ & -0.05 & $0.1 *$ & -0.03 & -0.06 & 0.08 & -0.02 & 0.01 & & \\
\hline $\mathrm{CE}$ & Career Exploration & -0.01 & $-0.16^{*}$ & -0.05 & $0.08^{*}$ & $0.26^{*}$ & $0.17^{*}$ & $0.21^{*}$ & -0.24 * & 0.03 & 0.02 & \\
\hline
\end{tabular}

Table 5. Summary of hypotheses and the effects of their verification.

\begin{tabular}{|c|c|c|}
\hline Hypotheses & $\begin{array}{l}\text { Confirmed versus Unconfirmed } \\
\text { Hypotheses }\end{array}$ & Interpretation \\
\hline Hypothesis 1 & Confirmed & $\begin{array}{l}\text { There is a relationship between participating in training } \\
\text { co-financed from the ESF and CE. The higher the CE } \\
\text { level, the greater the likelihood of participating in the } \\
\text { training. }\end{array}$ \\
\hline Hypothesis 2 & Confirmed & $\begin{array}{l}\text { Respondents with high CE more frequently indicate } \\
\text { that training co-financed under the ESF increased their } \\
\text { competitiveness on the labour market than persons } \\
\text { with low CE. }\end{array}$ \\
\hline Hypothesis 3 & Confirmed & $\begin{array}{l}\text { There is a relationship/negative correlation between the } \\
\text { level of CE and the answer that participants gained no } \\
\text { benefits from the training.Persons with high CE less } \\
\text { frequently indicated that they gained no benefits from } \\
\text { participating in the training co-financed under the ESF } \\
\text { than persons with low CE. }\end{array}$ \\
\hline Hypothesis 4 & Unconfirmed & $\begin{array}{l}\text { There is no correlation between CE and } \\
\text { non-participation in training co-financed under the ESF } \\
\text { on account of non-adjustment of a given offer to the } \\
\text { needs of the labour market. }\end{array}$ \\
\hline
\end{tabular}

The first hypothesis was confirmed. A statistically significant correlation $0.17(p<0.05)$ between $\mathrm{CE}$ and the use of training co-financed under the ESF was noted. The difference between average CE in the group of participants and non-participants of training is also statistically significant.

Hence, there is a link between participation in ESF training and the level of CE. The higher the level of $\mathrm{CE}$, the more frequently such persons participate in such training.

The second hypothesis was also confirmed. There is a statistically significant positive correlation $0.21(p<0.05)$ between high CE and the respondent's indication that training has increased his/her competitiveness on the labour market. The higher the level of $\mathrm{CE}$, the more frequently respondents indicate that a training co-financed under the ESF improved their competitiveness. 
There is a statistically significant negative correlation $-0.24(p<0.05)$ between high CE and an indication of a reply that a given training did not bring any benefits. So, the third hypothesis was also confirmed.

Conversely, the fourth hypothesis was not confirmed. There is a no correlation between CE and non-participation in training co-financed under the ESF on account of non-adjustment of a given offer to the needs of the labour market.

With regard to controlled variables, it is worth noting that participation in training correlates at the level of tendency solely with education. This means that the higher the educational degree, the higher the tendency of participating in training. The main demographic variables such as age or sex and place of residence are of no significance.

Persons employed indicated that the training brought them no benefits less frequently $(-0.13)$, whilst persons planning to change work/activity less frequently indicated that they did not participate in training co-financed under the ESF due to non-adjustment of the offer to the labour market $(-0.12)$.

On the other hand, CE correlates negatively with age $(-0.17)$ at the level of tendency, which means that older persons indicate a higher level of CE. A rather obvious dependency was identified, whereby persons planning to change work/economic activity have a higher level of $\mathrm{CE}(0.26)$.

At this occasion, it was also stated that women more frequently than men remain out of work. The higher the education, the greater the likelihood of having work (0.23). The place of residence turned out to be of importance for education and having work. The bigger the city a respondent lived in, the higher the educational degree (0.13) and the frequency of having work (0.12). It was also confirmed that older persons less frequently planned to change work $(-0.22)$. Even though these are not strong correlations, they do seem interesting from the point of view of reducing regional disparities and the objectives of regional policy.

Of course, the obtained results must be interpreted with a large dose of caution, nevertheless, they surely cannot be ignored in the context of the regional policy and a strive to achieve cohesion on the labour market.

\section{Discussion}

The aim of the research presented in the article was to check whether training co-financed from the ESF reached the group of beneficiaries whose psychological and competence potential does not allow for their independent activity on the labour market, thus determining the potential cause of delays in the region's development. In this way, it was specified whether the adopted solutions (under the National Development Programmes) support the process of Poland's sustainable development in terms of building competitiveness on the labour market.

It was assumed that the most advantageous situation exists when passive individuals with a low $\mathrm{CE}$ level benefit from training. Meanwhile, it was found that in the analysed programming period 2014-2020, training co-financed from the ESF was attended by people with a high CE level-i.e., those active on the labour market. This relationship indicates that the reach of training to economically inactive people is unsatisfactory, which reduces Poland's development potential in building competitiveness on the labour market.

It thus fails to sufficiently realize the goal of activating socially and professionally vulnerable or even excluded persons. Moreover, persons with higher education more frequently participate in training, even though the expected effect of the regional policy would be to activate those educationally neglected. All the more so when, as noted previously, persons with higher education more frequently have a job which is of significance for the labour market. However, the fact that persons with high CE clearly more frequently attended training must also be treated positively, especially that, thanks to this, they improved their competitiveness. Perhaps without this type of support, they could not have realized their plans related to changing work or line of business activity, which may be confirmed by the identified relation with CE. 
On the other hand, it was agreed that persons with high CE do not engage in the training that do not provide any benefits to them (negative correlation), especially if they are not adjusted to the labour market needs. From the point of view of investing the EU capital, it is of importance thanks to the attitude expressed by beneficiaries with high $\mathrm{CE}$ who participate in training only when they increase their competitiveness on the labour market. Apparent actions are in place when funds are spent on training, but their beneficiaries do not increase their competitiveness; thus, the goal of the policy is not realized. At the same time, absorption rate indicators may be satisfactory, but they do not trigger the expected economic processes that would even out the regional differences. In reality, those actions are ineffective.

In line with the adopted assumption, the goal of the EU cohesion policy (regional policy) impacts is to cause the expected actions among individuals in a given area that stimulate the desired cohesion processes. From the point of view of labour market needs, the CE feature of individuals seems to be particularly beneficial-they are active, consciously steer their development, time, etc. They constitute an advantage for a given region. Perhaps one ought to consider that they may determine its development potential, at least as regards the labour market. The obtained results of the research indicate that features of beneficiaries may constitute a barrier that limits or stimulates the efficiency of ESF tools and are worth considering.

Upon designing methods of intervention under the ESF as well as upon testing their efficiency, one should thus pay attention to the psychological and competitive potential of human capital. It is likely that the most costly and sophisticated methods will not function if individuals are unable to use them in the proper way.

The obtained results of tests provide arguments supporting the correctness of the thesis stated at the beginning of this article, whereby the human capital potential of a given region is of significance for its ability to use interventions, in this case training under the ESF. Further on, it accelerates or slows down the cohesion processes between regions.

The designed forms of financial intervention under the ESF seem, especially on the labour market, to consider the properties of individuals living in a given region that shape its specificity. Their design and analysis ought to come down to an individual level and not focus mainly on the more or less aggregated economic factors. The latter ones do not give us either the essence or the real picture of the situation of a given region when compared to other ones. They also offer different possibilities of reducing development disproportions. The research provided arguments in favour of the correctness of directing interventions to the regional level so that they could consider specific regional needs and potential contained in human capital, also on the level of an individual, to the fullest.

\section{Limitations and Further Research}

Impacts and interventions under the ESF are targeted at leading to cohesion on the labour market. This article verified the importance of human capital from the perspective of an individual. The starting point was a set of behaviours constituting Employability Market Orientation of a workpreneur adjusted to the rules of changing, short-term labour market. Within the research process, attention focused on one dimension, that is Employability Market Orientation, whilst the respondents originated from one country (Poland) being the largest recipient of the funds under the ESF.

The adopted research scheme is a source of legal restrains. They stem from the fact that attention focused on only one dimension of the functioning of entities and the relationship between it and the cultural specificity of the tested country. Therefore, it is worth considering the future verification of other psychological features, such as, for instance, the level of fear, stress or neuroticism from the Big Five. One may also consider more in-depth qualitative analyses, including a Focus Group Interview.

In the future, it might be worth conducting inter-regional and international tests. Results of comparative studies among the regions in terms of CE of inhabitants of areas along with the level of absorption of funds under the Regional Operating Programmes and the changes in economic factors in the context of designated goals of the regional policy would be interesting. 
The outcome might be an elaborated indicator of using the ESF that combines the level of committed financial resources with the type of applied intervention (i.e., training) and the psychological and competitive potential of human capital in a given region. This would allow for estimating the development potential of a region in terms of its use of the instruments of regional development policy.

\section{Practical Implications}

The results obtained in the presented research process have a number of significant implications. Above all, one may undertake actions on their basis which will facilitate reaching out to individuals on the labour market with interventions more effectively, overcoming potential difficulties in their activation.

According to Ch. M. Garofano and E. Salas [13], the skills related to Career Exploration may be trained and the process of education ought to support their improvement and provide knowledge about how to assess one's skills while shaping the need for further development. Properly incentivized entrepreneurs as employers may also joint this process under human resource management in an organization.

Thanks to developing the human capital potential in terms of the skills of proper use of interventions under the ESF, optimization of the funds invested in building competitiveness on the labour market also occurs. It also supports the growth of enterprises [28,29]. Ultimately, this increases the efficiency of conducted actions under regional development policy [30].

\section{Conclusions}

Financial instruments created by the ESF contribute to the permanent and sustainable development of regions and support the process of diversification of investment possibilities through realizing various forms of support.

The research process presented in this article has allowed for establishing that the higher the level of $\mathrm{CE}$ indicated by an individual as a workpreneur on the modern labour market, the more likely their participation in training co-financed under the ESF. Such persons more frequently indicated that the training had increased their competitiveness on the labour market, whilst there were fewer of those who noted it had brought them no benefits. In accordance with the adopted assumption, this means that the intervention under the ESF caused the expected behaviours stemming from the goals of regional policy, but within the group of persons better adjusted to the specificity of the modern labour market. This does not entirely match the assumptions of the ESF, in line with which the impacts also ought to activate passive recipients.

In this context, one ought to consider as positive the result of research that indicates that there is no correlation between CE and non-participation in training co-financed under the ESF on account of non-adjustment of a given offer to the needs of the labour market.

The adopted research process has permitted the main goal to be attained, where the importance of psychological and competency-related potential of human capital for implementing a policy serving the purpose of evening out regional differences on the labour market was noted.

Author Contributions: Conceptualization, visualization and writing-original draft-P.D.; Formal analysis, methodology and writing - original draft-A.P. All authors have read and agreed to the published version of the manuscript.

Funding: This research received no external funding.

Conflicts of Interest: The authors declare no conflict of interest.

\section{Appendix A}

Research survey (variables taken into consideration)

1. What is your sex?

- Male 
- Female

2. How old are you?

- $\quad 18-24$

- $\quad 25-34$

- $\quad 35-44$

- $\quad 45-54$

- $\quad 55-60$

3. Where do you live?

- Village

- Small town up to 20 thousand inhabitants

- Medium town from 20 to 99 thousand inhabitants

- $\quad$ Large town between 100 and 500 thousand inhabitants

- Large city above 500 thousand inhabitants

4. What is your current educational attainment (the last school you graduated from)?

- primary

- vocational

- secondary

- technical-YES/NO

- bachelor's degree

- master's degree

- doctoral student

- other

5. Indicate your employment status:

- $\quad$ Employed

- Own business

- $\quad$ Not working

6. Are you planning to change your job/business activity within the next year?

- Yes

- No

7. Rate on the scale how often you perform the following actions: The scale of answers: (1) never; (2) rarely; (3) often; (4) very often.

- I observe the labour market and the expectations of employers.

- I analyse job offers that give me a chance for professional development.

- I observe what forms of additional training people from my professional environment undergo.

- I check how many potential job offers there are for me in the market.

- I control what professional career others in my profession pursue.

- I look for information about a specific job or company as a potential workplace.

- I regularly talk to people who are well-informed about matters related to my profession.

- I gather information on how I can adapt to different career paths.

8. Have you ever participated in training co-financed from EU funds?

- Yes

- $\quad$ No 
9. If YES-Indicate what was influenced by the organized training:

- My competitiveness on the labour market increased

- It changed nothing-I did it for myself

10. If NO-Why did you not participate in training co-financed from EU funds?

- $\quad$ The offered training was not adapted to the labour market requirements

- If other, specify:

\section{References}

1. Deloitte. Global Human Capital Trends 2016. The New Organization: Different by design. April 2016. Available online: https:/www2.deloitte.com/content/dam/Deloitte/na/Documents/human-capital/BCTWF2016/na_HC_Trends_2016_presentation_BCTWF_Launch.pdf (accessed on 10 December 2016).

2. Górniak, J. (Ed.) Młodość czy Doświadczenie? Kapitał Ludzki w Polsce; Raport podsumowujący III edycje badań BKL z 2012 roku; PARP: Warsaw, Poland, 2013. Available online: http://bkl.parp.gov.pl/ (accessed on 10 October 2013).

3. Pawłowska, A.; Dubel, P. The Support for Micro-Enterprise Development to Reduce Unemployment. In New Socio-Economic Challenges of Development in Europe 2008; University of Latvia: Riga, Latvia, 2011.

4. Glinka, B. Contextualizing entrepreneurship: Perceptions of the context of entrepreneurship in Poland. In European Entrepreneurship Research and Practice: A Multifaceted Effort towards Integration of Different Perspectives; Pellegrini, M., Gnan, L., Lundberg, H., Raith, M., Songini, L., Starnawska, M., Eds.; Information Age Publishing: Charlotte, NC, USA, 2020.

5. Glinka, B.; Megyeri, G.; Tabajdi, G. Perception of entrepreneurship and entrepreneurs. Institutional celebration or stigmatisation? Int. J. Entrep. Small Bus. 2020; in press.

6. Dziewanowska, K.; Petrylaite, E.; Balas Rant, M.; Clegg, S. Personal Career Success in the Eyes of Nascent Entrepreneurs Internationally. Int. J. HRD Pract. Policy Res. 2019, 4, 25-44. [CrossRef]

7. Dubel, P. Analysis of the impact of the European Social Fund on the SME sector in Poland. Probl. Zarzadzania 2019, 17, 122-126. [CrossRef]

8. Postuła, M. Principles of Creating Government Programmes as a Basis of Their Efficiency—Polish Experiences. Przedsiębiorczość Zarzadzanie 2018, 10, 377-392.

9. EU publications. Mój Region, Moja Europa, Nasza Przyszłość. Siódmy Raport na Temat Spójności Gospodarczej, Społecznej i Terytorialnej; Dijkstra, L., Europejska, K., Generalna, D., Eds.; Polityki Regionalnej i Miejskiej: Brussels, Belgium, 2017; p. 192. Available online: https://ec.europa.eu/regional_policy/sources/docoffic/ official/reports/cohesion7/7cr_pl.pdf (accessed on 6 August 2020).

10. MIiR, Program Operacyjny Wiedza Edukacja Rozwój 2014-2020. pp. 29-34. Available online: https: //www.power.gov.pl/media/83902/Program_Wiedza_Edukacja_Rozwoj_2014-2020_2019.pdf (accessed on 6 August 2020).

11. Irodenko, O. Czynniki efektywności audytu wewnętrznego jako istotnego elementu zarządzania przedsiębiorstwem—badanie teoretyczne. In Przedsiębiorczość w Teorii i Badaniach. Perspektywa Młodych Badaczy; Postuła, A., Darecki, M., Eds.; Wydawnictwo Naukowe Wydziału Zarządzania Uniwersytetu Warszawskiego: Warsaw, Poland, 2017.

12. Waters, L.; Briscoe, J.P.; Hall, D.T.; Wang, L. Protean career attitudes during unemployment and reemployment: A longitudinal perspective. J. Vocat. Behav. 2014, 84, 405-419. [CrossRef]

13. Garofano, C.M.; Salas, E. What influences continuous employee development decisions? Hum. Resour. Manag. Rev. 2005, 15, 281-304. [CrossRef]

14. Akkermans, J.; Brenninkmeijer, V.; Schaufeli, W.B.; Roland, W.B. Blonk. It's all about career skills: Effectiveness of a career development intervention for young employees. Hum. Resour. Manag. 2015, 54, 533-551. [CrossRef]

15. Pawłowska, A. Zatrudnialność Pracobiorcy w Elastycznym Zarzadzaniu Ludźmi; PWE: Warsaw, Poland, 2017; pp. $80-82$.

16. Frey, A.; Grill, J. Pracoprzedsiębiorca: Model Pracownika Przyszłości; Narodowe Forum Doradztwa Kariery: Kraków, Poland, 2015; pp. 10-12.

17. Eby, L.T.; Butts, M.; Lockwood, A. Predictors of success in the era of the boundaryless career. J. Organ. Behav. 2003, 24, 689-708. [CrossRef] 
18. Wenga, Q.; McElroy, J.C. Vocational self-concept crystallization as a mediator of the relationship between career self-management and job decision effectiveness. J. Vocat. Behav. 2010, 76, 234-243. [CrossRef]

19. Koen, J.; Klehe, U.C.; Annelies, E.M.; Vianen, V.; Zikic, J.; Nauta, A. Job-search strategies and reemployment quality The impact of career adaptability. J. Vocat. Behav. 2010, 77, 126-139. [CrossRef]

20. Flum, H.; Blustein, D.L. Reinvigorating the Study of Vocational Exploration: A Framework for Research. J. Vocat. Behav. 2000, 56, 380-404. [CrossRef]

21. Majczyk, J. Strategies of venture development. In Immigrant Entrepreneurship: Cases from Contemporary Poland; Glinka, B., Jelonek, A.W., Eds.; Routledge: New York, NY, USA, 2020; pp. 119-146.

22. Zikic, J.; Saks, A.M. Job search and social cognitive theory: The role of career-relevant activities. J. Vocat. Behav. 2009, 74, 117-127. [CrossRef]

23. Guzman, A.B.; Ok Choi, K. The relations of employability skills to career adaptability among technical school students. J. Vocat. Behav. 2013, 82, 199-207. [CrossRef]

24. Werbel, J.D. Relationships among Career Exploration, Job Search Intensity, and Job Search Effectiveness in Graduating College Students. J. Vocat. Behav. 2000, 57, 379-394. [CrossRef]

25. Hofstede, G. Kultury i Organizacje: Zaprogramowanie Umystu; PWE: Warsaw, Poland, 2011; p. 32.

26. Van der Heijde, C.M.; Van der Heijden, B.I.J.M. A competence-based and multidimensional operationalization and measurement of employability. Hum. Resour. Manag. 2006, 45, 449-476. [CrossRef]

27. Stumpf, S.A.; Colarelli, S.M.; Hartman, K. Development of the Career Exploration Survey (CES). J. Vocat. Behav. 1983, 22, 191-226. [CrossRef]

28. Baruch, Y. The development and validation of a measure for protean career orientation. Int. J. Hum. Resour. Manag. 2014, 25, 2702-2723. [CrossRef]

29. Kalleberg, A.L. Precarious Work Insecure Workers: Employment Relations in Transition. Am. Sociol. Rev. 2009, 74, 11-22. [CrossRef]

30. Dubel, P. Regional Policy and Barriers to Access to EU Founds for the SME Sector in 2007-2013. Stud. Eur. Aff. 2018, 3, 247-250.

Publisher's Note: MDPI stays neutral with regard to jurisdictional claims in published maps and institutional affiliations.

(C) 2020 by the authors. Licensee MDPI, Basel, Switzerland. This article is an open access article distributed under the terms and conditions of the Creative Commons Attribution (CC BY) license (http://creativecommons.org/licenses/by/4.0/). 